\title{
Effect of Microwave Power and Extraction Time on Crude Palm Oil Quality Using Microwave-Assisted Extraction Process
}

\author{
Norashikin Ahmad Zamanhuri, Norazah Abd Rahman*, Noor Fitrah Abu Bakar
}

Faculty of Chemical Engineering, Universiti Teknologi MARA, 40450 Shah Alam, Selangor, Malaysia

\begin{abstract}
The aim of this study is to evaluate microwave-assisted extraction at several microwave power and extraction time in extracting oil palm products, such as crude palm oil (CPO) and palm fatty acid (PFA) composition. The exposure time was shortened and overheating was avoided when sterilized mesocarp exposed to microwave prior to Soxhlet extraction in order to obtain good quality oil. The effects of CPO extraction and PFA composition on the distillate produced were investigated. Gas chromatography coupled with mass spectrometry (GC-MS) was used for the determination and quantification of PFA composition in the distilled products. Scanning electron microscopy (SEM) reveals that the microwave-assisted extraction technique had efficiently assisted in the release of oil by breaking down the mesocarp cell structure. To fill the research gap of microwave-assisted sterilization in the previous research, microwave-assisted extraction was introduced, in which two processes (i.e., extraction and drying) were conducted in one equipment. Oil yield and color, free fatty acids (FFA), Deterioration of Bleachability Index (DOBI), and carotene contents of the CPO were quantified. At $100 \mathrm{~W}$, the extraction of CPO demonstrated $64 \%$ yield produced, with chemical properties of $0.301 \%$ FFA, 3.53 DOBI and 1132 ppm carotene with final temperature of $76.2^{\circ} \mathrm{C}$ during microwave-assisted extraction. The optimum condition for extracting PFA distillate was $300 \mathrm{~W}$ for 30 min of exposure time. Additionally, distillate obtained at the optimum condition using microwave-assisted extraction consisted of high palmitic acid (C16:0), caramel-like aroma, and possessed a sweet fragrance.
\end{abstract}

Keywords: Microwave, Sterilization, Extraction, Crude Palm Oil, Palm Fatty Acids

Article History: Received: 29 ${ }^{\text {th }}$ Sept 2020; Revised: 30 th Dec 2020; Accepted: $15^{\text {th }}$ Feb 2021; Available online: $25^{\text {th }}$ Feb 2021

How to Cite This Article: Zamanhuri, N.A., Rahman, N.A., and Abu Bakar, N.F. (2021) Effect of microwave power and extraction time on crude palm oil (CPO) quality using microwave-assisted extraction process. International Journal of Renewable Energy Development, $10(3), 495-505$. https://doi.org/10.14710/ijred.2021.35402

\section{Introduction}

The first step of palm oil milling is the initial detachment of individual fruits from its bunch, which is called sterilization and stripping process (Cheng et al., 2021; Vincent, 2014). It is important that the fruits are heated immediately after harvest to stop the breakdown of palm oil into free fatty acids (FFA) (Ngando et al., 2006). Inadequate sterilization affects subsequent milling processing stages adversely. With the FFA of crude oil below $5 \%$, the quality of the oil is categorized as excellent. Moreover, the FFA content from fruit spikelet with major damage during harvesting and transportation can reach up to $5 \%$ in the absence of immediate pretreatment process (Chong \& Sambanthamurthi, 1993).

Much research has addressed that one-third of the major source of waste water in milling process is formed by the steam condensate coming out of the sterilizer (Lam \& Lee, 2011; Lau et al., 2008). Most oil losses in palm oil mills occur in the fiber, sludge, and sterilizer condensate, thus, more than $50 \%$ of the water will end up as palm oil mill effluent (POME). Consequently, it leads to huge consumption of water that is eventually exhausted into the atmosphere and is said to be hazardous to the environment (Latifahmad et al., 2003; Sulaiman et al.,
2010). Existing palm oil milling process does not involve solvent extraction, but the process uses a combination of physical and mechanical approaches. Conventional process produces about $2 \%$ residual oil per fruit in the fruit fiber, which is wasted and contributes to high oil loss (Chavarro et al., 2014).

In recent years, microwave technology has been studied as a replacement for sterilization process in oil palm industry. The palm fruits need to be freshly harvested. Extended exposure at ambient temperature condition strongly affects the level of free fatty acids (FFA), which is an important determinant of oil quality. Chow and $\mathrm{Ma}$ (2007) reported that microwave technology is suitable for detachment and sterilization of oil palm fruit compared with conventional mechanical wet processing. More valuable minor components in the fruits can be derived from the exhaustive solvent extraction of mesocarp using appropriate solvents, such as carotenoids, fatty acid derivatives, and tocopherols. The use of hexane in solvent extraction outperforms mechanical extraction in terms of oil yield and quality (Cheng et al., 2011). Higher retention of carotene content and vitamin $\mathrm{E}$ was found from the exhaustive solvent extraction of CPO.

Sukaribin and Khalid (2009) reported that the highest moisture content in the abscission layer between the

\footnotetext{
* Corresponding author: noraz695@uitm.edu.my
} 
pedicel and mesocarp on the oil palm bunch is suitable for fast detachment of the fruitlet without damaging oil palm fruits in microwave heating. However, the aforementioned researchers found that extended microwave exposure was observed to have burned the fruit, showing a significant increase in drying and therefore, resulting in cracking and browning of the mesocarp and kernel.

After examining the effectiveness of microwave technology-assisted sterilization in terms of fruits stripping and exposure time, respectively, the focus of future studies should be on quality oil. Free fatty acids (FFA) in oil are one way to measure the quality of oil produced. In the last two decades, extraction aided by microwave technology has received great attention from numerous researchers for its attractive features, such as its appeal as a green and safe extraction technique. Water is a main source for microwave interactions due to its dipolar nature. Drying using microwave energy is increased by $50 \%$, leading to faster rates and shorter processing times compared with conventional hot air drying. Microwave heating is characterized by rapid volumetric heating with advantages such as faster throughputs, space and energy savings, and quality improvements (Foong et al., 2020). For example, when exposed with sufficient water, the fruit expands and subsequently, the fiber ruptures and escapes from the fiber (Li et al., 2013).

To improve the application of microwave-assisted sterilization and prevent FFA content in CPO from increasing, a microwave-assisted extraction of oil palm mesocarp has been proposed in this study, where two processes (i.e., extraction and drying) were done using one equipment. The focus in microwave-assisted extraction is attributable to its rapid heat production in materials as a result of water molecular orientation that will increase the internal temperature during microwave heating (Sarah $e t$ $a l ., 2020)$. In order to obtain an optimum extraction yield, the dried fruits must have a moisture content less than $10 \%$ for the extraction process to be able to recover valuable minor components and obtain efficient extraction. Soxhlet extraction technique was used to extract crude palm oil after sterilizing via microwave. Nokkaew and Punsuvon, (2016) found that the oil yield and moisture content of the mesocarp are feasible for extraction and evaluation, respectively, using microwave drying at $6 \mathrm{~min}$ to replace oven drying for $24 \mathrm{~h}$ prior to Soxhlet extraction.

This study evaluates the feasibility of microwave- assisted extraction of oil palm mesocarps as an alternative processing method which acts as both a drier and an extractor. Effects of microwave power and extraction time on yield and composition of the PFA were investigated. Other quality parameters such as free fatty acids, Deterioration of Bleachability Index, and carotene content were determined. The results were compared with those obtained via extracted crude palm oil at several conditions and assessed both qualitatively and quantitatively.

\section{Materials and Methods}

\subsection{Material and Sample Preparation}

Oil palm fruits were obtained from oil palm plantations at Selangor, Malaysia. All chemicals used were of analytical grade and supplied from Merck. An n-hexane with a purity of $95 \%$ was obtained from Merck, Malaysia, and deionized water was used as solvent.

\subsection{Microwave-Assisted Extraction}

Microwave-assisted sterilization and extraction process is performed in a microwave oven (Panasonic, NNST651M, Malaysia) with a frequency of $2450 \mathrm{MHz}$ and a maximum delivery power of $1000 \mathrm{~W}$. The interior cavity dimensions of the oven are $35.5(\mathrm{~W}) \times 25.1(\mathrm{H}) \times 35.6(\mathrm{D})$ $\mathrm{cm}$. During experiment, power and time are controllable variables. The microwave oven was modified by drilling a hole at the top. A flat bottom quartz reactor with a capacity of $1000 \mathrm{ml}$ was placed in the cavity and connected to a condenser through the hole (Ferhat et al., 2006; Virot et al., 2008), as illustrated in Fig. 1. The temperature was monitored using a shielded K-type thermocouple (SE-305) that was inserted directly into the quartz flask. Prior to the extraction, fresh oil palm fruit spikelets were sterilized to retain its quality and reduce the increase of FFA within the fruits. The sterilization process was conducted at $800 \mathrm{~W}$ and $6 \mathrm{~min}$ of irradiation time with a ratio of fruitto-water of 1:0.5 (Zamanhuri et al., 2017).

After completing the microwave-assisted sterilization, the oil palm fruits were taken out from the microwave and cooled down to room temperature. The sterilized fruits were then peeled manually from the nut using a stainlesssteel blade, as depicted in Fig. 2 (b). Mesocarp mass of $100 \mathrm{~g}$ was determined during preliminary experiment to establish the appropriate bed thickness and identify the distribution of electromagnetic wave and its dielectric properties, as well as the moisture content at fixed extraction time and microwave power (Zamanhuri et al., 2019).

The manually peeled off oil palm mesocarp was moistened prior to extraction by soaking the sample in $200 \mathrm{~g}$ of water. This step is essential to give initial moisture for peeling purposes. The moistened peeled off sample was placed in a flat bottom quartz flask that was connected to a cooling system apparatus, as shown in Fig. 1 (b). Several microwave power levels of 100, 300, 400, and $600 \mathrm{~W}$ and extraction time of $20,25,30,35$, and $40 \mathrm{~min}$ were investigated via the application of microwaveassisted extraction. Extraction experiment were performed in three replicates. The cooling system outside the microwave oven had condensed the distillate continuously at $5^{\circ} \mathrm{C}$.

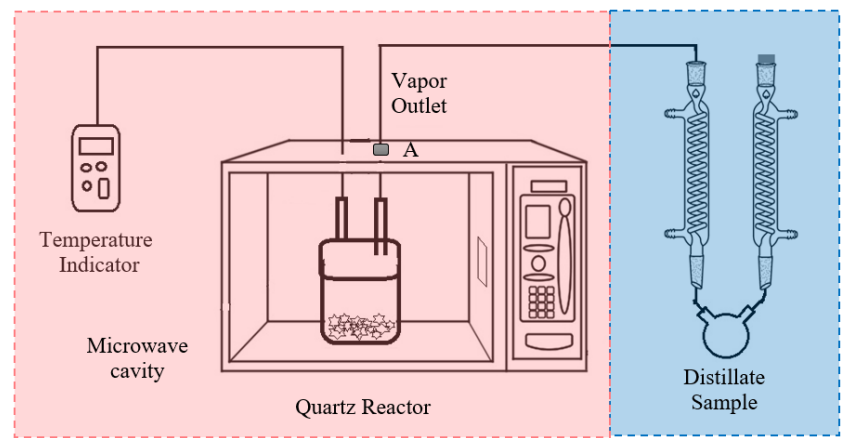

(a)

(b)

Fig. 1 Schematic diagram of: (a) microwave-assisted sterilization; and (b) extraction. 


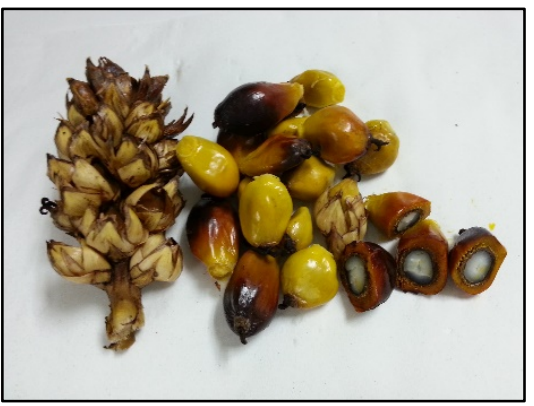

(a)

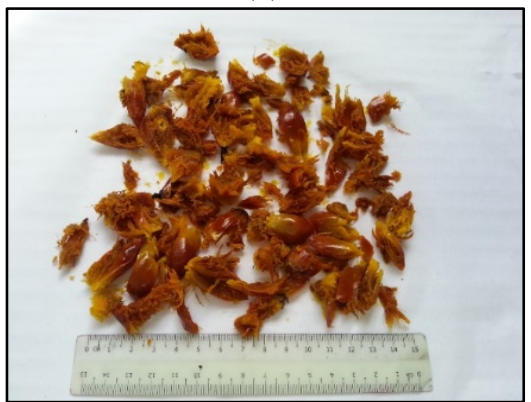

(b)

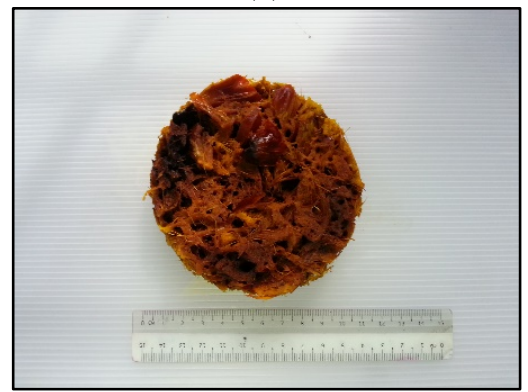

(c)

Fig. 2 (a) Sterilized and completely detached oil palm fruits spikelet; (b) Manually peeled off oil palm mesocarp prior to extraction; and (c) Dried mesocarp obtained by microwaveassisted extraction.

For comparison purposes, the same samples, as shown in Fig 2 (b), were subjected to hexane extraction using Soxhlet extractor (Nokkaew \& Punsuvon, 2014; Ali, Shamsudin, \& Yunus, 2014). The extraction was conducted using solvent, i.e., hexane-to-solid ratio of 15:1 and $300 \mathrm{ml}$ of pure hexane was added into $20 \mathrm{~g}$ of dried mesocarp sample in an 8-hour extraction time, as proposed in Malaysian Palm Oil Board (MPOB) Test Methods (Ainie Kuntom, 2004) and in an earlier study (Ali et al., 2014). The extracted CPO was obtained after removing hexane using a rotary evaporator (Heidolph Laborata 4000) at a vacuum pressure and water bath temperature of $55^{\circ} \mathrm{C}$. The sample is denoted as $\mathrm{SE}$ throughout the discussion.

The steam produced during microwave-assisted extraction was condensed at $5^{\circ} \mathrm{C}$ through a cooling system (Fig. 1 (b)). The extractive was clarified using a separating funnel, where it was left to stand for $60 \mathrm{~min}$ at room temperature to form two distinguished layers of palm fatty acid (PFA) compositions: extractant (hexane) and water (Ye et al., 2016). The clear PFA layer was dried with anhydrous sodium sulphate to remove any moisture prior to its injection into the gas chromatography (GC Varian 450-GC) for analysis.

\subsection{Characterization of Crude Palm Oil (CPO)}

Oil extraction yield is defined as weight of total extracted oil (gram) per weight of mesocarp (gram) on wet weight basis at respective mesocarp mass, exposure time, and microwave power level. The oil yields were calculated using Eq. (1).

$$
\begin{aligned}
& \text { Yield }\left(\frac{\text { goil }}{\text { g sample feed }}\right) \\
& \qquad=\left(\frac{\text { extracted oil }(g)}{\text { sample feed }(g)}\right) \times 100 \%
\end{aligned}
$$

Determination of free fatty acid (FFA), Deterioration of Bleachability Index (DOBI) and carotene content were carried out using the Malaysian Palm Oil Board (MPOB) Test Methods. The FFA content was measured using titration method, as instructed in the MPOB Test Methods manual, with some modifications (Ainie Kuntom, 2004). A 2 -g solution of preheated oil of about $50^{\circ} \mathrm{C}$ was mixed with $75 \mathrm{ml}$ of isopropyl alcohol. The mixture was neutralized by titration with $0.100 \mathrm{~N}$ sodium hydroxide $(\mathrm{NaOH})$. The percentage of FFA content was calculated using Eq. (2).

$$
\% F F A=\frac{25.6 \times V \times N}{w}
$$

where: $V=$ volume of sodium hydroxide used, $N=0.100$ $\mathrm{N}$ is normality (concentration) of sodium hydroxide used, and $w=$ weight of oil used.

Deterioration of Bleachability Index (DOBI) was measured using the MPOB Test Methods (Ainie Kuntom, 2004). About $0.1 \mathrm{~g}$ of oil was weighed and dissolved in $25 \mathrm{ml}$ of absolute hexane (95\%). The oil sample was placed in a $1-\mathrm{cm}$ cuvette and an absorbance reading was taken at $446 \mathrm{~nm}$ and $269 \mathrm{~nm}$ by using the UV-Vis Spectrophotometer (Lambda 750, Perkin Elmer). DOBI value was defined as the ratio of spectrophotometric absorbance at 446 and $269 \mathrm{~nm}$, as shown in Eq. (3).

$$
D O B I=\frac{\text { Absorbance at } 446 \mathrm{~nm}}{\text { Absorbance at } 269 \mathrm{~nm}}
$$

The B-carotene content was measured according to the MPOB Test Methods (Ainie Kuntom, 2004). The oil was heated between $60^{\circ} \mathrm{C}-70^{\circ} \mathrm{C}$ and homogenized thoroughly. The oil was filtered using a filter paper (Whatman No.1) to remove any impurities. The oil was weighed at $0.1 \mathrm{~g}$ and placed into a $25-\mathrm{ml}$ volumetric flask and diluted with $\mathrm{n}$ hexane. The oil sample was then transferred into a $1-\mathrm{cm}$ cuvette and measured at $446 \mathrm{~nm}$ of spectrophotometric absorbance to the solvent. The cuvette error was also measured at the same wavelength. The equation of $B$ carotene was calculated by Eq. (4), where: $a_{s}=$ absorbance of the sample, $a_{b}=$ cuvette error, and $w=$ weight of sample in $\mathrm{g}$.

$$
\beta-\text { carotene }(\text { ppm })=\frac{25 \times 383 \times\left[a_{s}-a_{b}\right]}{100 \times w}
$$




\subsection{GC-MS Analysis of Distillate Palm Fatty Acids (PFA)}

Fig. 1 (b) demonstrates the composition of the distillate collected, which was determined using a gas chromatography mass spectrometer (GC Varian 450-GC). Helium was used as a carrier gas at a flow rate of $1 \mathrm{ml} / \mathrm{min}$. A non-polar capillary column (Type: BP5MS GC Columns) was selected for detection of $\mathrm{C}$ and $\mathrm{H}$ atoms or $\mathrm{C}-\mathrm{C}$ bonds. The oven temperature was initially set at $100^{\circ} \mathrm{C}$ and kept constant for 2 minutes at a heating rate of $5^{\circ} \mathrm{C} / \mathrm{min}$. Subsequently, the oven temperature was increased to $200^{\circ} \mathrm{C}$ at a heating rate of $10^{\circ} \mathrm{C} / \mathrm{min}$ and further heated to $206^{\circ} \mathrm{C}$ at a heating rate of $4^{\circ} \mathrm{C} / \mathrm{min}$. The temperature was maintained at $240^{\circ} \mathrm{C}$ for 15 minutes. For chromatography, the injection temperature was set at $270^{\circ} \mathrm{C}$.

\subsection{Morphological Characterization}

Surface textures of the raw and treated oil palm mesocarp samples were observed using a scanning electron microscope (SEM) (Hitachi Tabletop Microscope, TM3000) at an accelerating voltage of $10 \mathrm{kV}$. The samples were airdried and sputtered with gold in a Mini Sputter Coater (Quorum Technologies, Model SC7620) for 45 seconds prior to SEM observation.

\section{Results and Discussion}

\subsection{Effects of microwave power level}

Fig. 3 (a) shows the effect of microwave power towards the formation of oil yield and color via microwave-assisted extraction at a constant irradiation time of 30 minutes. From the preliminary study, it was found that 30 minutes was sufficient to dry the oil palm mesocarp prior to extracting the CPO and simultaneously producing the distillate PFA. The required microwave power was directly related to sample size and weight. In this case, the weight was fixed at $100 \mathrm{~g}$ based on the penetration depth, $D p$, as studied in previous research (Zamanhuri et al., 2019). During microwave heating of mesocarp, electromagnetic energy was generated by electron tube called magnetron and absorbed by the mesocarp. Microwave causes water molecules in mesocarp to vibrate and thus, produce heat energy.

The maximum CPO produced was at $100 \mathrm{~W}$, higher by $4.29 \%$ than the CPO extracted without the usage of microwave-assisted extraction, i.e., $0 \mathrm{~W}$. However, the extracted oil yield decreased to $59.15 \%$ and $40.04 \%$ at $400 \mathrm{~W}$ and $600 \mathrm{~W}$, respectively. During the experiment, there was an unpleasant smell detected when the exposure power was increased to $600 \mathrm{~W}$ at the final temperature of $199.8^{\circ} \mathrm{C}$. The extracted CPO yield decreased with increasing microwave power levels. Increasing of microwave power in oil palm mesocarp may result in physical damage, such as burning and overheating.

Increasing the microwave power creates a few undesirable observations, such as the dark and burned mesocarp in the quartz vessel which indicates extreme decomposition, resulting in the extracted oil of dark brown color, as shown in Fig. 3 (b). The microwave power must be sufficient to reach the boiling point of water, which affects the extraction temperature, i.e., presence of microwaves that are attracted to water, which can reduce the moisture content of the sample and lead to cracking for the release of the target compound. As a result, cell walls in the mesocarp would rupture easily. A possible explanation is that this sufficient microwave power provides enough driving force to break down the plant cell matrix but not enough to spoil the oil quality.

This observation was also reported by other researchers on a similar work by Thammarat (2015), where their microwave radiation pretreatment of mango seed kernel with increasing microwave power may have resulted in physical damage, such as burning, overheating, and uneven temperature distribution. These phenomena are close to those reported by Kha et al. (2013), who also worked on Gac oil extraction. In the abovementioned work, it was learned that the application of microwave power should not be too high, ranging between 630 and $900 \mathrm{~W}$; otherwise, there would be a loss of volatile compounds and degradation of target compounds. Thus, $100 \mathrm{~W}$ was found to be sufficient for producing the highest CPO yield via the microwaveassisted extraction process.

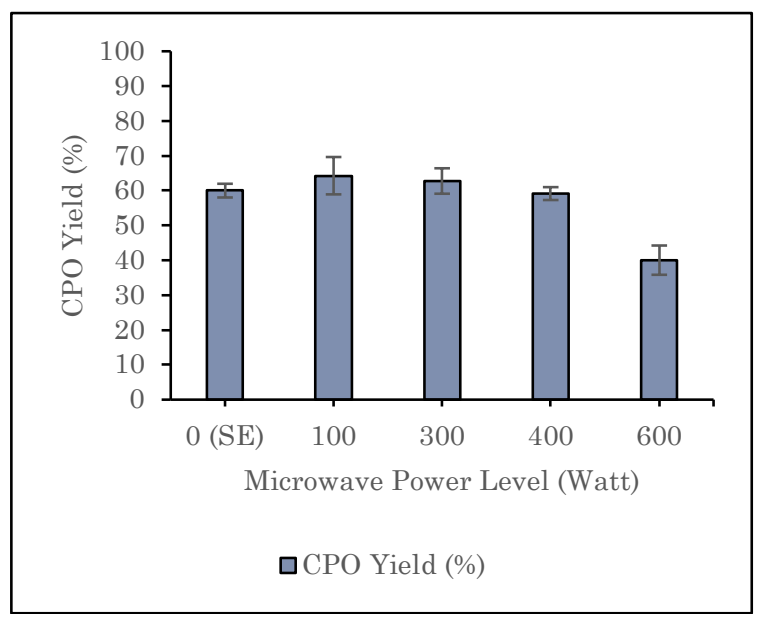

(a)

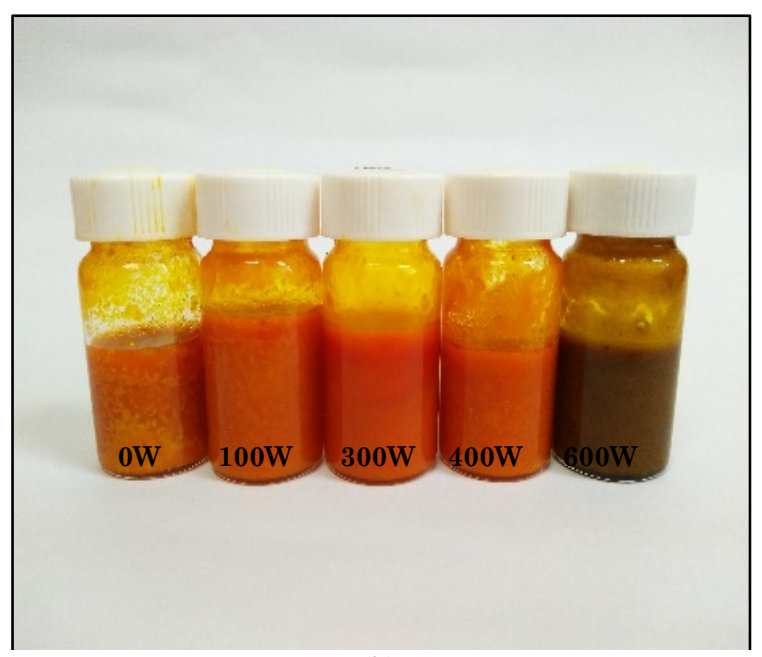

(b)

Fig. 3 Effect of microwave power on CPO extraction in terms of: (a) yield; and (b) color. 
Fig. 4 (a) shows the percentage of free fatty acids (FFA) (\% based on palmitic acid) and Deterioration of Bleachability Index, DOBI, in the crude palm oil for microwave power from 100 to $600 \mathrm{~W}$. During Soxhlet Extraction $(0 \mathrm{~W})$, the result indicates FFA of $0.351 \%$; while at $100 \mathrm{~W}$ of microwave power, the FFA was $0.301 \%$. However, at $600 \mathrm{~W}$, the FFA slightly increased to $0.311 \%$. A minimal increment in FFA content was observed although further extension of microwave exposure was found to produce burned mesocarp. This observation was also reported by other researchers (Cheng et al., 2011; Tan, Chuah, \& Cheng, 2016) who had conducted a similar work and obtained CPO with low FFA content for all microwave exposure within the duration of 1-4 min at $800 \mathrm{~W}$. The FFA content was almost comparable to that in refined palm oil. The Palm Oil Refiners Association of Malaysia (PORAM) standard specifications for the FFA content (as palmitic acid) is 5\% maximum in CPO and $0.1 \%$ maximum in refined-bleached-deodorized (RBD) oils. Low FFA in CPO shows good physicochemical properties because the increasing level of FFA in CPO of more than $5 \%$ is not recommended as edible oil for human consumption. Instead, an FFA content in CPO of more than $5 \%$ is beneficial for many different products, such as animal feeds, laundry soaps, and the oleochemical industry, where it is utilized mostly as a source of fatty acid for non-food application industry.

Fig. 4 (a) portrays the effects of microwave power towards Deterioration of Bleachability Index (DOBI) of extracted crude palm oil (CPO). The highest grade of DOBI for the commercial CPO in palm oil mill has been documented to be above 3.24, good between 2.93-3.24, fair between 2.31-2.92, and poor between 1.78-2.30 (Vincent, Shamsudin, \& Baharuddin, 2014). According to Silva et al. (2014), DOBI is the most reliable tool to predict the ease of refining in the case of $\mathrm{CPO}$. The result indicates that without microwave power, i.e., during SE, the DOBI value was 2.53, indicating fair quality of CPO. Extracted CPO using microwave-assisted extraction contained an acceptable level of oxidation products with an average DOBI value of 3.53 and 2.77 at $100 \mathrm{~W}$ and $300 \mathrm{~W}$, respectively.

This downward trend of DOBI at 100 Wand $300 \mathrm{~W}$ in microwave-assisted extraction may be due to further exposure to high microwave power that resulted in high temperature, thus deteriorating the palm oil. On the other hand, microwave-assisted extraction may aid the reduction of bleaching earth, which is another waste that can possibly be minimized in the refinery. However, when oil palm mesocarp is exposed to a higher power at 400 and $600 \mathrm{~W}$, the oil started to deteriorate and the DOBI value dropped to 1.54 and 0.50 , respectively. These findings are in good agreement with a study reported by Nokkaew \& Punsuvon (2014), whereby high temperature during high power microwave degraded the carotene content in palm oil, therefore, directly producing low DOBI.

The maximum carotene amount and final temperature in the CPO sample from microwave-assisted extraction was obtained at $1132 \mathrm{ppm}$ and $76.2^{\circ} \mathrm{C}(100 \mathrm{~W})$, while the lowest amount was at $614 \mathrm{ppm}$ and $199.8^{\circ} \mathrm{C}(600 \mathrm{~W})$, as shown in Fig. 4 (b). Typical CPO contains 500-700 ppm carotene content, which contributes to palm oil stability and provides the richest source of carotenoid that acts as an antioxidant (Mba, Dumont, \& Ngadi, 2015; Silva et al.,
2014). This could probably be due to the shorter sterilization time (Zamanhuri et al., 2017) and lower extraction temperature used by microwave-assisted extraction at $100 \mathrm{~W}$, which consequently reduces carotene degradation. Nevertheless, there was a significant loss of carotene content when the power was increased to $600 \mathrm{~W}$. The carotene concentration increased proportionally with an increasing microwave power of up to $500 \mathrm{~W}$ in its first stage power, whereby subsequently, an increase in microwave power resulted in poor carotene concentrations (Wang et al., 2008; Chan et al., 2011). High microwave power, i.e., relatively above $630 \mathrm{~W}$, might deteriorate the nutrients (Kha et al., 2013). Therefore, carotene concentration in crude palm oil produced at $600 \mathrm{~W}$ was the lowest because the carotenes were subject to thermal degradation and oxidation process, especially under processing condition with a final temperature of $199.8^{\circ} \mathrm{C}$.

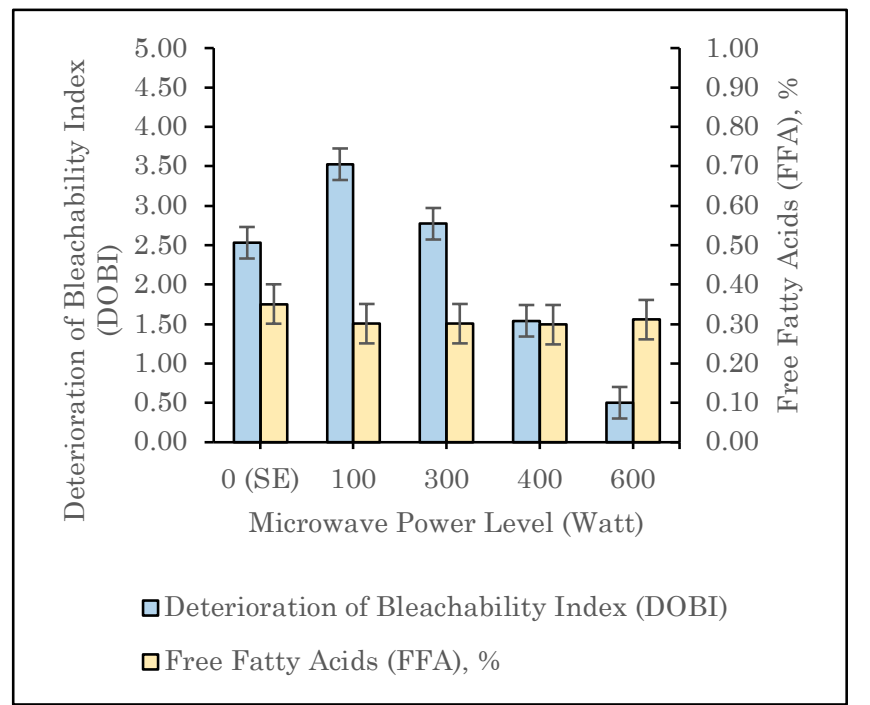

(a)

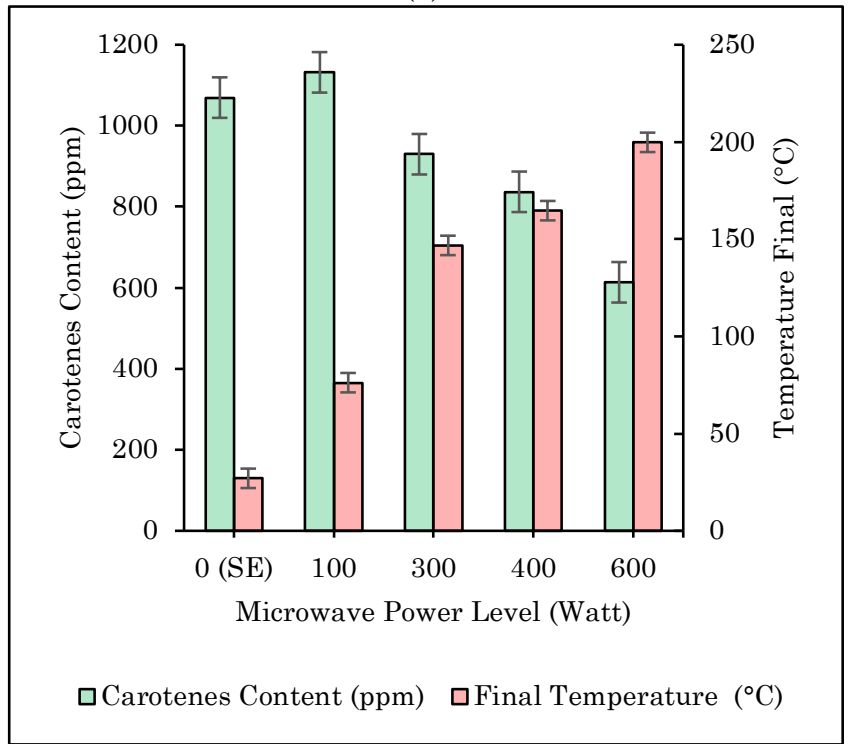

(b)

Fig. 4 Effect of microwave power on: (a) Deterioration of Bleachability Index (DOBI) and free fatty acids (FFA); and (b) carotene content and final temperature at a constant extraction time of $30 \mathrm{~min}$. Note: $24 \mathrm{~h}$ of oven drying prior to Soxhlet extraction (SE). 


\subsection{Effects of extraction time}

Figs. 5 and 6 show the effects of extraction time towards extracted oil yield, color, FFA (\% based on palmitic acid), DOBI, and carotene content using microwave-assisted extraction at $300 \mathrm{~W}$. Microwave power was fixed at $300 \mathrm{~W}$ because it is the minimum power level that can produce distillate and study the effects of extraction time. Figs. 5 (a) and (b) show that within the extraction time of 20 to 30 minutes, this technique produced good extraction of $\mathrm{CPO}$ in terms of yield and color. However, when the extraction time was extended to 40 minutes, CPO yield was decreased to $38.45 \%$ and the oil color turned black. Long exposure to microwave will change the color of red orange palm oil with high content of carotenoids to dark color palm oil. This is in agreement with previous studies that highlighted the significance of irradiation time on the oil yield (Franco-Vega et al., 2015; Golmakani \& Rezaei, 2008). The average CPO extraction rate from the conventional process in commercial palm oil was recorded at $20.21 \%$ (Board, 2020).

The overall result indicated that the oil yield from microwave-assisted extraction is comparable to the extracted oil yields via Soxhlet extraction (SE) while producing a composition of distillate oil palm fruits that possessed sweet fragrance (i.e., the smell is comparable to that of a coconut candy). Both methods produced the same amount of yield, 65.58-68.98\%. In the microwave-assisted extraction, the microwave induced a sudden temperature increase within a few seconds inside the cellular structure, which may have caused the rupture of cell structure that promoted the rapid release of oil. This observation was also reported by other researchers (Tan et al., 2016) who had conducted a similar work in a combined process of microwave pretreatment, followed by hexane extraction, where an optimized duration would ensure high efficiency of extraction.

Fig. 6 (a) shows the effect of extraction time on DOBI and FFA at a constant microwave power of $300 \mathrm{~W}$. The FFA average value is $0.313 \%$ within 20 to $30 \mathrm{~min}$, but after 30 minutes, the FFA began to rise until $0.680 \%$. However, this value is considered acceptable for the FFA content. The percentage of FFA reflects the degree of oil hydrolysis, which is possibly caused by the presence of moisture under prolonged heating and enzymatic hydrolysis of oil before sterilization. According to Bahadi et al. (2016) and Japir et al. (2016), for trading purposes, the FFA content in CPO must not exceed 5\%. The obtained FFA content via microwave-assisted extraction is comparable to that of refined palm oil. Although the typical FFA content is in the range of $3-5 \%$, it should be kept as low as possible for better palm oil quality and lower refining cost (Tan et al., 2009).

CPO extracted using microwave-assisted extraction consists of an acceptable level of oxidation products with an average DOBI value of $2.70,2.82,2,77$, and 2.45 for 20 , 25, 30, and 35 minutes, respectively. However, as the exposure duration was extended, there was a significant decrease in DOBI value. It was also observed that microwave exposure has a significant effect on the extracted oil. Long microwave exposure was found to produce burned oil and degraded carotene content in CPO that directly contribute to the low DOBI value.

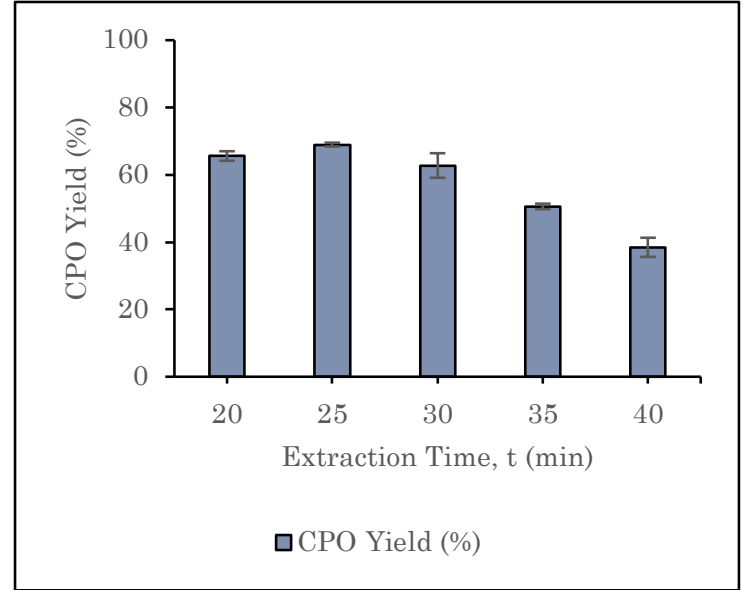

(a)

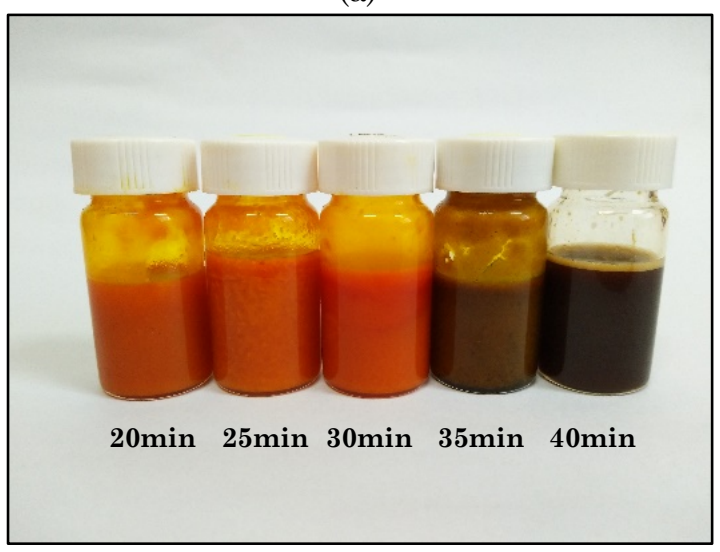

(b)

Fig. 5 Effect of extraction time on CPO in terms of its: (a) extraction yield; and (b) color.

The carotene content in the extracted oil using microwave-assisted extraction was above the range of typical CPO with 548-1156 ppm, as shown in Fig. 6 (a). A relatively high acceptable amount of carotene was found in the extracted oil in the present study and it is on the high range of the specification. However, during microwave-assisted extraction process, the temperature of the mesocarp reached $150.6^{\circ} \mathrm{C}$ when the material was exposed for $40 \mathrm{~min}$, producing the lowest carotene content of $548 \mathrm{ppm}$. The dark and burned mesocarp clearly indicates that extreme decomposition had occurred and as a result, the extracted oil was also black in color. This finding is in agreement with those reported by Cheng et al. (2011), Nokkaew \& Punsuvon (2014), and Mejri et al. (2010), where the duration of extraction and proportion of water used in the extraction system had influenced the level of carotene content.

In general, the extracted crude palm oil shows good quality when compared to the oil obtained from the palm mill, and it is deemed suitable for edible purposes. Microwave-assisted extraction is said to be suitable for drying the mesocarp before oil is extracted, rather than using an oven for $24 \mathrm{~h}$ to dry the mesocarp. With the aid of microwave, extraction can be completed in minutes instead of hours without organic solvents while providing the ability to collect evaporated water vapor formed from this process. During the microwave-assisted extraction process, evaporated water, known as distillate, was collected for further investigation. 


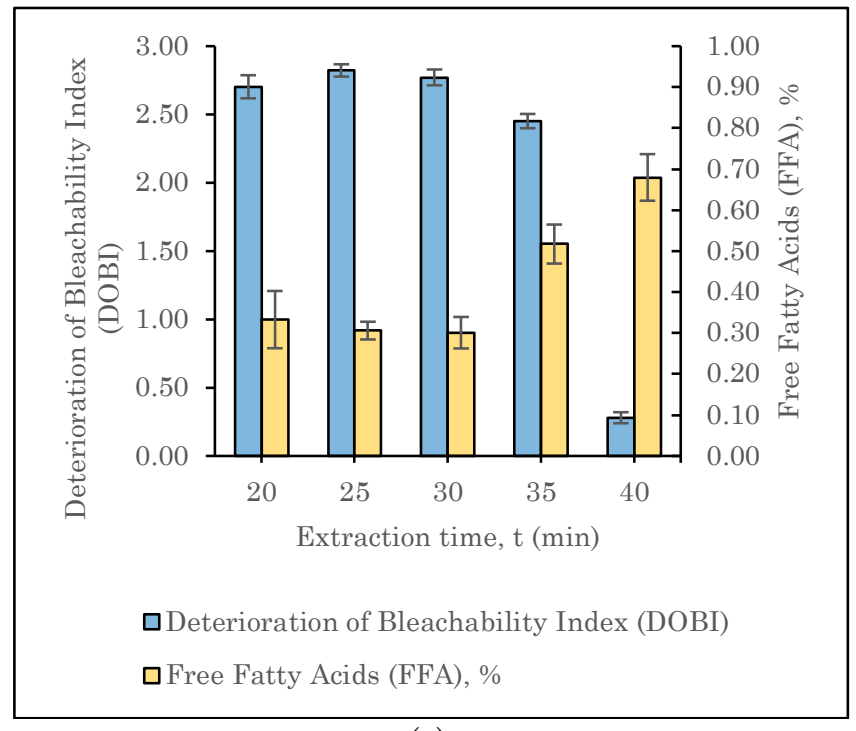

(a)

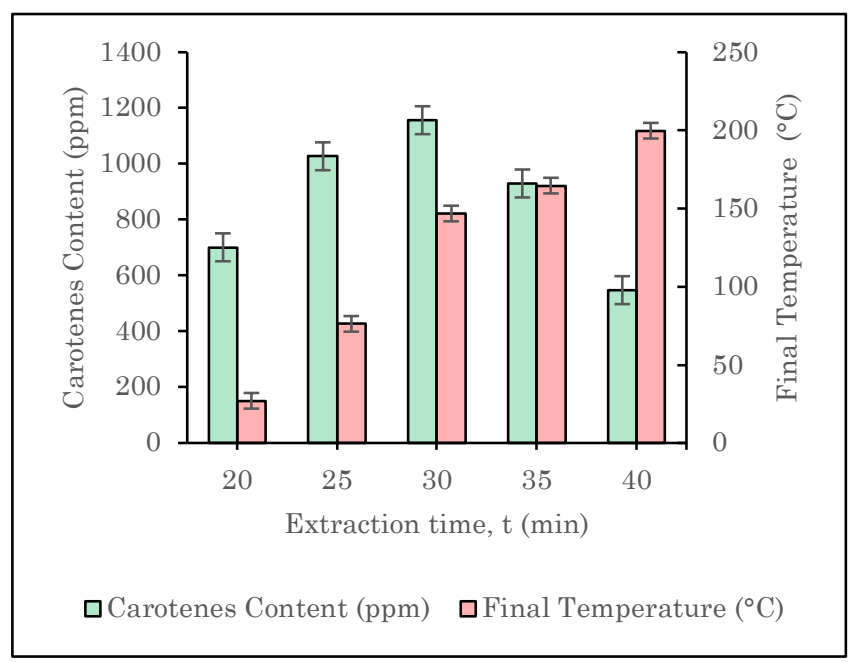

(b)

Fig. 6 Effect of extraction time on: (a) Deterioration of Bleachability Index (DOBI) and free fatty acids (FFA); and (b) carotene content and temperature final at a constant microwave power of $300 \mathrm{~W}$.

\subsection{Composition of Distillate}

A power level of $300 \mathrm{~W}$ was selected as the most suitable condition that would simultaneously produce CPO and distillates. In this work, it was desirable to establish the best microwave processing time in the distillate's composition during microwave-assisted extraction. Table 1 illustrates palm fatty acids (PFA) composition of oil palm mesocarp distillate, which had a sweet fragrance when extracted at 20,30, and 40 minutes and $300 \mathrm{~W}$. The distillate produced after microwave-assisted extraction process is a colorless liquid. The results of GC-MS analysis showed that there are several saturated PFA, i.e., lauric acid (C12:0), palmitic acid (C16:0), and stearic acid (C18:0), in the distillate. The major constituent of PFA is palmitic acid (C16:0), which is best extracted at a microwave power of $300 \mathrm{~W}$. When the extraction time was increased from 20 to 40 minutes, the percentage of palmitic acid decreased in terms of total PFA produced. This finding is similar to results found in the literature (Pramote et al., 2002). The PFA, which is water soluble at high temperatures ranging between $60^{\circ} \mathrm{C}$ and $230^{\circ} \mathrm{C}$, can be evaporated together with water when the palm fruit mesocarp are heated with microwave. The values obtained in this study are also similar to those reported by $\mathrm{Hu}$ et al. (2017).

The microwave-assisted extraction mechanism involved three sequential steps that began with diffusion of solutes, i.e., PFA from the palm fruit mesocarp to the surface. When irradiated with sufficient microwave power, the water in the oil palm fruit mesocarp expands and subsequently escapes from the oil palm fruit mesocarp, with the expansion rupturing the fiber. Then, the PFA compound will be transferred into the solvent, i.e., water, followed by the evaporation of the PFA compound out of the extraction quartz vessel. The results from Pramote et al. (2002) also showed the solubility of the long-chain fatty acids, such as palmitic and stearic acids, which increased dramatically with increasing temperature than that of the short-chain fatty acids, such as lauric acids. The aforementioned work also concluded that the solubility of PFA in water increased with increasing temperature and decreased with increasing carbon (Yezdimer et al., 2001).

Table 1

Palm fatty acid (PFA) composition of oil palm mesocarp according to the GC-MS analysis results

\begin{tabular}{|c|c|c|c|c|c|c|}
\hline \multirow{3}{*}{ Fatty Acid Composition } & \multicolumn{6}{|c|}{ Extraction Time (min) } \\
\hline & \multicolumn{2}{|r|}{20} & \multicolumn{2}{|r|}{30} & \multicolumn{2}{|r|}{40} \\
\hline & $\begin{array}{c}\text { RT } \\
(\mathrm{min})\end{array}$ & $\begin{array}{c}\% \\
\text { Compound }\end{array}$ & $\begin{array}{c}\text { RT } \\
(\mathrm{min})\end{array}$ & $\begin{array}{c}\% \\
\text { Compound }\end{array}$ & $\begin{array}{c}\text { RT } \\
(\mathrm{min})\end{array}$ & $\%$ Compound \\
\hline \multicolumn{7}{|l|}{ Saturated } \\
\hline Lauric C12:0 & 14.1 & 2.625 & 14.2 & 7.682 & 14.2 & 3.175 \\
\hline Palmitic C16:0 & 8.9 & 9.134 & 8.9 & 18.913 & 8.9 & 15.827 \\
\hline Stearic C18:0 & 17.1 & 5.204 & 15.6 & 7.826 & 15.6 & 1.599 \\
\hline \multicolumn{7}{|l|}{ Monounsaturated } \\
\hline Palmitoleic C16:1 & 16.7 & 6.209 & 16.8 & ND & 16.7 & 1.700 \\
\hline Oleic C18:1 & 5.7 & ND & 5.9 & ND & 17.7 & ND \\
\hline
\end{tabular}




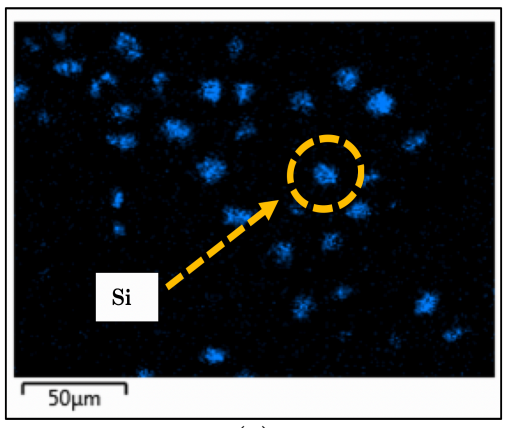

(a)

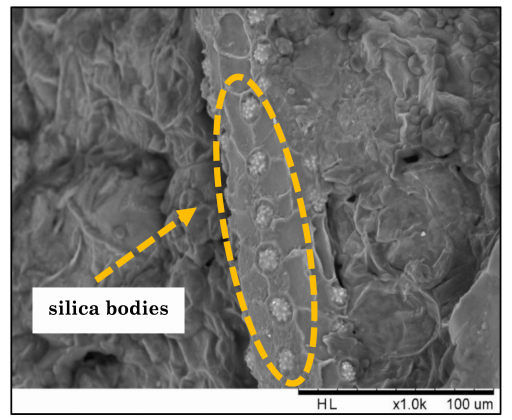

(c)

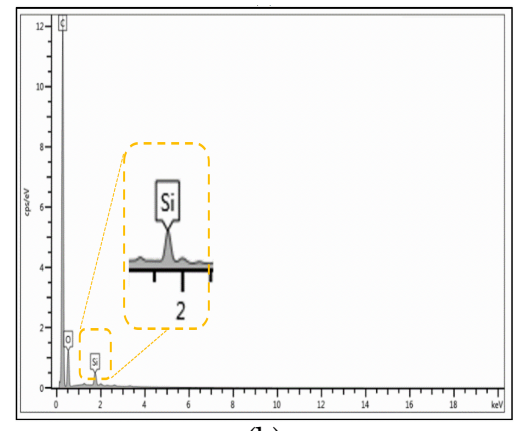

(b)

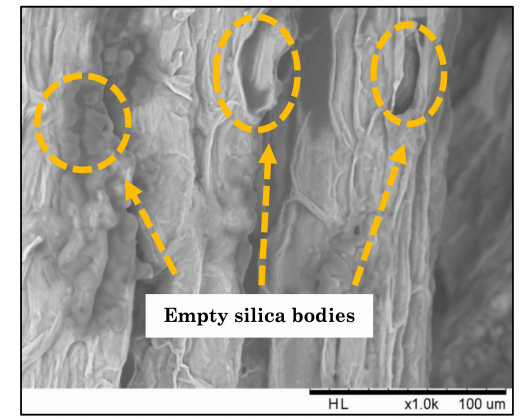

(d)
Fig. 7 SEM: (a) mapping of raw oil palm mesocarp; (b) microanalysis spectrum of raw oil palm mesocarp that indicates the particle is silica; (c) micrographs of fiber surface of raw oil palm mesocarp; (d) fiber surface treated oil palm mesocarp with microwave-assisted sterilization; and (e) fiber surface of microwave-assisted extraction.

\subsection{Morphological Analysis}

Scanning electron microscope (SEM) was used to observe the morphology of oil palm mesocarp at different conditions, as shown in Fig. 7. There are three conditions that have been classified as: (1) raw oil palm mesocarp, (2) oil palm mesocarp after microwave-assisted sterilization, and finally, (3) oil palm mesocarp after microwave-assisted-extraction process. Fig. 7 (a) shows the image of SEM mapping, where the blue particles represent silica bodies. The finding is supported by EDX analysis, which is shown in Fig. 7 (b). The spectrum of elements present in the fiber surface demonstrated that the particles were silica. There were obvious changes between the surface morphology of raw oil palm mesocarp and microwave-exposed oil palm mesocarp. Initially, the surface of the raw oil palm mesocarp, i.e., fibers, appeared to be rough and rigid, as seen in Fig. 7 (c). In addition, the fibers of raw oil palm mesocarp were found to be arranged in highly ordered fibrils. Based on the images in Fig. 7(c), raw oil palm mesocarp is observed to have a number of silica bodies embedded in the fiber structure. Silica bodies act as a shield to protect the plant structure and concurrently enhance its mechanical strength (Currie \& Perry, 2007). The presence of silica bodies inside the pores would not facilitate oil extraction. According to Law et al. (2007), silica bodies within 10 to $15 \mu \mathrm{m}$ in diameter were spread uniformly over the strand surface. This finding was similar with the previous study, in which silica bodies were observed on the surface of oil palm empty fruit bunch
(OPEFB), which are partly embedded in the surface along the longitudinal direction of the fiber (Omar, Mohammed and Baharuddin, 2014).

Subsequent to microwave-assisted sterilization at $800 \mathrm{~W}$, ratio $(\mathrm{m}: \mathrm{v})$ of 1:0.5, and irradiation time of $6 \mathrm{~min}$, some of the silica bodies inside the pores of sterilized oil palm mesocarp were partially removed, as depicted in Fig. 7 (d). Energy produced at this condition during sterilization phase is sufficient to halt the rise in FFA. Meanwhile, during the extraction phase, microwave exposure is required to induce more rupture of the cell walls for more efficient extraction.

During microwave-assisted extraction, when experiment was conducted at the extraction phase of $300 \mathrm{~W}$ and $30 \mathrm{~min}$, the outer layer of the oil palm mesocarp's inner structure was distorted and disintegrated. The removal of silica bodies is more apparent in Fig. 7 (e). Furthermore, some cracks and micropores can be clearly seen on the strand of oil palm mesocarp structure. Microwave irradiation, as previously reported (Porto et al., 2016), can boost oil extraction yield due to cell membrane rupture, which results in generating permanent pores and transferring oil from the permeable cell walls. Since most of the oil-bearing cells are plant tissue, the presence of water and heat increases the probability of hydrolysis, whereby oil-bearing cells would be ruptured. For microwave-assisted extraction, in situ water molecule in the plant cells is promoted to rotate under microwave irradiation, thus, immediate internal change of water molecule 
develops a subsequent pressure that leads to the breakdown of cell walls and release of oil molecules. There is clear evidence of a cell breakdown occurring at the cell level as a consequence of sudden temperature rise generated at located hot spots caused by microwave power (Ma et al., 2012; Bousbia et al., 2009). The moisture content of natural plant materials, microwave power, and extraction time are also influencing parameters for the yield of plant compounds (Chan et al., 2011; Ma et al., 2012).

\section{Conclusion}

Microwave-assisted sterilization and extraction is highly effective for the extraction of oil palm fruits, which improved the quality of CPO upon treatment. A caramel-like aroma was released after posttreatment, which was then evaporated by the in situ water of the oil palm mesocarp. These novel processes can also sterilize the oil palm fruits concurrently while the microwave energy strongly disrupts the cell walls and free from any residual solvent. Additionally, the distillate obtained has a higher palmitic acid content (C16:0) and the chemical properties of CPO are $64 \%$ yield, $0.301 \%$ FFA, 3.53 DOBI, and 1132 ppm carotene content. All chemical properties have met the requirements of commercial CPO standards.

Based on a relatively simple principle, this process is neither a modified solvent-free microwave extraction without the use of organic solvents, nor a modified hydrodistillation which uses a large quantity of water. Microwave-assisted extraction is a faster, more effective, and more environmentally friendly approach, making it a promising tool for CPO extraction and PFA distillates.

\section{Acknowledgments}

The authors gratefully acknowledge the financial support received from Ministry of Higher Education Malaysia through research grant, Research Management Institute (RMI), and Faculty of Chemical Engineering, Universiti Teknologi MARA, Shah Alam, Selangor, Malaysia.

\section{References}

Abd, A. J., Jumat, S., Darfizzi, D., Murad, B., Muhammad, R. Y. (2016). Purification of High Free Fatty Acid Crude Palm Oil Using Molecular Distillation. Asian Journal of Chemistry, 28(11), 2549-2554. https://doi.org/10.14233/ajchem.2016.20095

Ainie, K. (2004). Methods of test for palm and palm oil products (1) (2). Malaysian Palm Oil Board (MPOB).

Ali, F. S., Shamsudin, R., \& Yunus, R. (2014). The Effect of Storage Time of Chopped Oil Palm Fruit Bunches on the Palm Oil Quality. Agriculture and Agricultural Science Procedia, 2 , https://doi.org/10.1016/j.aaspro.2014.11.024
Bahadi, M. A., Salimon, J., \& Japir, A.-W. M. (2016). The physicochemical and thermal properties of Malaysian high free fatty acid crude palm oil. American Institute of Physics, 030002, 030002. https://doi.org/10.1063/1.4966740

Bayramoglu, B., Sahin, S., \& Sumnu, G. (2008). Solvent-free microwave extraction of essential oil from oregano. Journal of Food Engineering, 88(4), 535-540. https://doi.org/10.1016/j.jfoodeng.2008.03.015

Board, M. P. (2020). OER Performance of Malaysian Oil Palm Mills - January 2020.

Bousbia, N., Abert Vian, M., Ferhat, M. A., Petitcolas, E., Meklati, B. Y., \& Chemat, F. (2009). Comparison of two isolation methods for essential oil from rosemary leaves: Hydrodistillation and microwave hydrodiffusion and gravity. Food Chemistry, 114(1), 355-362. https://doi.org/10.1016/j.foodchem.2008.09.106

Chan, C.-H., Yusoff, R., Ngoh, G.-C., \& Kung, F. W.-L. (2011). Microwave-assisted extractions of active ingredients from plants. Journal of Chromatography A, 1218(37), 62136225. https://doi.org/10.1016/j.chroma.2011.07.040

Chavarro, J., Mokhtar, M. N., Sulaiman, A., Samsu, A., Busu, Z., Gomez, J. C., ... Baharuddin, A. S. (2014). Recovery of Residual Crude Palm Oil from the Empty Fruit Bunch Spikelets Using Environmentally Friendly Processes. Separation Science and Technology, (June 2015), 37-41. https://doi.org/10.1080/01496395.2014.994781

Cheng, S. F., Nor L., M., \& Chuah, C. H. (2011). Microwave pretreatment: A clean and dry method for palm oil production. Industrial Crops and Products, 34(1), 967-971. https://doi.org/10.1016/j.indcrop.2011.03.002

Cheng, Y. W., Chong, C. C., Lam, M. K., Ayoub, M., Cheng, C. K., Lim, J. W., ... Bai, J. (2021). Holistic process evaluation of non-conventional palm oil mill effluent (POME) treatment technologies: A conceptual and comparative review. Journal of Hazardous Materials, 409(December 2020), 124964. https://doi.org/10.1016/j.jhazmat.2020.124964

Chong, C. L., \& Sambanthamurthi, R. (1993). Effects of mesocarp bruising on the rate of free fatty acid release in oil palm fruits. International Biodeterioration and Biodegradation, 31(1), 65-70. https://doi.org/10.1016/0964-8305(93)90015$\mathrm{T}$

Chow, M. C., \& Ma, A. N. (2007). Processing of fresh palm fruits using microwaves. Journal of Microwave Power and Electromagnetic Energy, 40(3), 165-173. Retrieved from http://www.scopus.com/inward/record.url?eid=2-s2.034447504389\&partnerID=tZOtx3y1

Currie, H. A., \& Perry, C. C. (2007). Silica in plants: Biological, biochemical and chemical studies. Annals of Botany, 100(7), 1383-1389. https://doi.org/10.1093/aob/mcm247

Da Porto, C., Decorti, D., \& Natolino, A. (2016). Microwave pretreatment of Moringa oleifera seed: Effect on oil obtained by pilot-scale supercritical carbon dioxide extraction and Soxhlet apparatus. The Journal of Supercritical Fluids, 107, 38-43. https://doi.org/10.1016/j.supflu.2015.08.006

Ferhat, M. A., Meklati, B. Y., Smadja, J., \& Chemat, F. (2006). An improved microwave Clevenger apparatus for distillation of essential oils from orange peel. Journal of Chromatography A, 1112(1-2), 121-126. https://doi.org/10.1016/j.chroma.2005.12.030

Foong, S. Y., Liew, R. K., Yang, Y., Cheng, Y. W., Yek, P. N. Y., Wan Mahari, W. A., ... Lam, S. S. (2020). Valorization of biomass waste to engineered activated biochar by microwave pyrolysis: Progress, challenges, and future directions. Chemical Engineering Journal, 389(February), 124401. https://doi.org/10.1016/j.cej.2020.124401

Franco-Vega, A., Ramírez-Corona, N., Palou, E., \& López-Malo, A. (2015). Estimation of mass transfer coefficients of the extraction process of essential oil from orange peel using microwave-assisted extraction. Journal of Food Engineering, 170, 136-143. https://doi.org/10.1016/j.jfoodeng.2015.09.025

Golmakani, M.-T., \& Rezaei, K. (2008). Comparison of microwave- 
assisted hydrodistillation withthe traditional hydrodistillation method in the extractionof essential oils from Thymus vulgaris L. Food Chemistry, 109(4), 925-930. https://doi.org/10.1016/j.foodchem.2007.12.084

Hu, B., Li, C., Zhang, Z., zhao, Q., Zhu, Y., Su, Z., \& Chen, Y. (2017). Microwave-assisted extraction of silkworm pupal oil and evaluation of its fatty acid composition, physicochemical properties and antioxidant activities. Food Chemistry, 231, 348-355. https://doi.org/10.1016/j.foodchem.2017.03.152

Japir, A. A. W., Salimon, J., Derawi, D., Bahadi, M., \& Yusop, M. R. (2016). Separation of free fatty acids from high free fatty acid crude palm oil using short-path distillation. AIP Conference Proceedings, 1784. https://doi.org/10.1063/1.4966739

Kha, T. C., Nguyen, M. H., Roach, P. D., \& Stathopoulos, C. E. (2013). Effects of Gac aril microwave processing conditions on oil extraction efficiency, and B-carotene and lycopene contents. Journal of Food Engineering, 117(4), 486-491. https://doi.org/10.1016/j.jfoodeng.2012.10.021

Lam, M. K., \& Lee, K. T. (2011). Renewable and sustainable bioenergies production from palm oil mill effluent (POME): Win-win strategies toward better environmental protection. Biotechnology Advances, 29(1), 124-141. https://doi.org/10.1016/j.biotechadv.2010.10.001

Latifahmad, A., Ismail, S., Bhatia, S., Ahmad, A. L., Ismail, S., \& Bhatia, S. (2003). Water recycling from palm oil mill effluent (POME) using membrane technology. Desalination, 157(1-3), 87-95. https://doi.org/10.1016/S0011-9164(03)00387-4

Law, K. N., Daud, W. R. W., \& Ghazali, A. (2007). Morphological and chemical nature of fiber strands of oil palm emptyfruit-bunch (OPEFB). BioResources, 2(3), 351-362. https://doi.org/10.15376/biores.2.3.351-362

Li, Y., Fabiano-Tixier, A. S., Vian, M. A., \& Chemat, F. (2013). Solvent-free microwave extraction of bioactive compounds provides a tool for green analytical chemistry. TrAC Trends in Analytical Chemistry, 47, 1-11. https://doi.org/10.1016/j.trac.2013.02.007

Lik, N. L., Choo, Y. M., Ma, A. N., \& Chuah, C. H. (2008). Selective extraction of palm carotene and vitamin $\mathrm{E}$ from fresh palmpressed mesocarp fiber (Elaeis guineensis) using supercritical CO2. Journal of Food Engineering, 84(2), 289-296. https://doi.org/10.1016/j.jfoodeng.2007.05.018

Ma, C., Yang, L., Zu, Y., \& Liu, T. (2012). Optimization of conditions of solvent-free microwave extraction and study on antioxidant capacity of essential oil from Schisandra chinensis (Turcz.) Baill. Food Chemistry, 134(4), 25322539. https://doi.org/10.1016/j.foodchem.2012.04.080

Mba, O. I., Dumont, M.-J., \& Ngadi, M. (2015). Palm oil: Processing, characterization and utilization in the food industry - A review. Food Bioscience, 10, 26-41. https://doi.org/10.1016/j.fbio.2015.01.003

Mejri, J., Abderrabba, M., \& Mejri, M. (2010). Chemical composition of the essential oil of Ruta chalepensis L: Influence of drying, hydro-distillation duration and plant parts. Industrial Crops and Products, 32(3), 671-673. https://doi.org/10.1016/j.indcrop.2010.05.002

Ngando, E. G. F., Dhouib, R., Carrière, F., Amvam, Z. P. H., \& Arondel, V. (2006). Assaying lipase activity from oil palm fruit (Elaeis guineensis Jacq.) mesocarp. Plant Physiology and Biochemistry, 44(10), 611-617. https://doi.org/10.1016/j.plaphy.2006.09.006

Nokkaew, R., \& Punsuvon, V. (2014). Sterilization of oil palm fruits by microwave heating for replacing steam treatment in palm oil mill process. Advanced Materials Research, 1025-1026, 470-475. https://doi.org/10.4028/www.scientific.net/AMR.10251026.470

Omar, F. N., Mohammed, M. a. P., \& Baharuddin, a. S. (2014). Effect of Silica Bodies on The Mechanical Behaviour of Oil Palm Empty Fruit Bunch Fibers. BioResources, 9(4), 7041-
7058.

Pramote, K., Shuji, A., \& Ryuichi, M. (2002). Solubility of Saturated Fatty Acids in Water at Elevated Temperatures. Bioscience, Biotechnology, and Biochemistry, 66(8), 17231726. https://doi.org/10.1271/bbb.66.1723

Sahraoui, N., Vian, M. A., Bornard, I., Boutekedjiret, C., \& Chemat, F. (2008). Improved microwave steam distillation apparatus for isolation of essential oils. Comparison with conventional steam distillation. Journal of Chromatography A, 1210(2), 229-233. https://doi.org/10.1016/j.chroma.2008.09.078

Sarah, M., Hisham, M. F., Rizki, M., \& Erwinda, R. (2020). Effect of power and time in pectin production from cocoa pod husk using microwave-assisted extraction technique. International Journal of Renewable Energy Development, 9(1), 125-130. https://doi.org/10.14710/ijred.9.1.123-130

Silva, S. M., Sampaio, K. A., Ceriani, R., Verh, R., Stevens, C., De Greyt, W., \& Meirelles, A. J. A. (2014). Effect of type of bleaching earth on the final color of refined palm oil. $L W T$ Food Science and Technology, 59(2P2), 1258-1264. https://doi.org/10.1016/j.lwt.2014.05.028

Sukaribin, N., \& Khalid, K. (2009). Effectiveness of sterilisation of oil palm bunch using microwave technology. Industrial Crops and Products, 30(2), 179-183. https://doi.org/10.1016/j.indcrop.2009.05.001

Sulaiman, F., Abdullah, N., Gerhauser, H., Shariff, A. (2010). A Perspective of Oil Palm and Its Wastes. Journal of Physical Science, 21(May), 67-77. Retrieved from http://web.usm.my/jps/21-1-10/16753402_21.1.6.pdf

Tan, C.-H., Ghazali, H. M., Kuntom, A., Tan, C.-P., \& Ariffin, A. a. (2009). Extraction and physicochemical properties of low free fatty acid crude palm oil. Food Chemistry, 113(2), 645650. https://doi.org/10.1016/j.foodchem.2008.07.052

Tan, J. C. X., Chuah, C.-H., \& Cheng, S.-F. (2016). A combined microwave pretreatment/solvent extraction process for the production of oil from palm fruit: Optimisation, oil quality and effect of prolonged exposure. Journal of the Science of Food and Agriculture, (January). https://doi.org/10.1002/jsfa.7975

Thammarat, N. S. (2015). Effect of microwaves pretreatments on extraction yield and quality of mango seed kernel oil. International Food Research Journal, 22(3), 960-964.

Vincent, C. J., Shamsudin, R., \& Baharuddin, A. S. (2014). Pretreatment of oil palm fruits: A review. Journal of Food Engineering, 143 https://doi.org/10.1016/j.jfoodeng.2014.06.022

Virot, M., Tomao, V., Ginies, C., Visinoni, F., \& Chemat, F. (2008). Green procedure with a green solvent for fats and oils' determination. Journal of Chromatography A, 1196-1197, 147-152. https://doi.org/10.1016/j.chroma.2008.04.035

Wang, J., Wang, Y. W., Wang, J. W., \& He, X. L. (2008). Drying characteristics and drying quality of kidney beans using a two-stage microwave process. Journal of Food Process Engineering, $31(3)$, 413-430. https://doi.org/10.1111/j.1745-4549.2007.00170.x

Ye, W., Gao, Y., Ding, H., Liu, M., Liu, S., Han, X., \& Qi, J. (2016). Kinetics of transesterification of palm oil under conventional heating and microwave irradiation, using $\mathrm{CaO}$ as heterogeneous catalyst. Fuel, 180, 574-579. https://doi.org/10.1016/j.fuel.2016.04.084

Yezdimer, E. M., Chialvo, A. A., \& Cummings, P. T. (2001). Examination of chain length effects on the solubility of alkanes in near-critical and supercritical aqueous solutions. Journal of Physical Chemistry B, 105(4), 841847. https://doi.org/10.1021/jp002610r

Zamanhuri, N. A., Rahman, N. A., \& Abu Bakar, N. F. (2017). Effect of Various Power Level and Different Ratio of Fruit to Water in Oil Palm Fruits Microwave Sterilizer. Malaysian Journal of Analytical Sciences, 21(4), 941-949. https://doi.org/10.17576/mjas-2017-2104-21

Zamanhuri, N. A., Rahman, N. A., \& Abu Bakar, N. F.(2019). Determination of Mesocarp Mass for Effective Heating in 
Int. Journal of Renewable Energy Development 10 (3) 2021: 495-505

Microwave-assisted Sterilization and Extraction ( MASE )

of Oil Palm Fruits. International Journal of Recent

Technology and Engineering (IJRTE), 8(1), 3162-3166.

(C) 2021. This article is an open access article distributed under the terms and conditions of the Creative Commons Attribution-

ShareAlike 4.0 (CC BY-SA) International License (http://creativecommons.org/licenses/by-sa/4.0/) 